This is an open access article under the CC BY-NC-ND license (https://creativecommons.org/licenses/by-nc-nd/3.0/) Issue III, November 2020

ISSN 2707-9481

ISBN 978-601-323-207-2

https://doi.org/10.31643/2020.013

\author{
Gabiden Suleimenov \\ Al-Farabi Kazakh National University, Kazakhstan \\ E-mail: gabiden1604@gmail.com \\ ORCID ID 0000-0002-9341-7408
}

\title{
An initial-boundary value problem for Boltzmann's non-stationary nonlinear one-dimensional four-moment system of equations
}

\begin{abstract}
In this article, the set of boundary conditions is defined for first and boundary value problems for the second approximation of Boltzmann's system of one-dimensional nonlinear moment equations and their logic. For the second approximation of Boltzmann's one-dimensional non-stationary nonlinear moment equations, which satisfies the Maxwell-Auzhan boundary condition, the theorem for the first boundary problem is considered and by proving this theorem, it is proved that there are only solutions to the given problems. It is known that in many problems of gas dynamics there is no need to describe the complete state of the gas by the function of microscopic distribution of molecules. Therefore, it is better to look for an easier way to describe the gas using macroscopic gas - dynamic variables (density, hydrodynamic average velocity, temperature) are determined in this rotations by the moments of the microscopic distribution function of the molecules, the author faced with the problem of analyzing the different moments of the Boltzmann equation. By studying the moment equations, the author obtained some information about the function of the microscopic distribution of molecules and the convergence of the moment method.

Keywords: Boltzmann's moment system of equations, Vladimirov-Marshak's boundary condition, MaxwellAuzhan's boundary condition, iterative algorithms.

Cite this article as: Suleimenov G., (2020). Bolcmannıng ctacionar emec cızıqcız birolşemdi toptmomenttik tengdeuler juiyeci ushin algaşq1-şettik ecep [An initial-boundary value problem for Boltzmann's nonstationary nonlinear one-dimensional four-moment system of equations]. Challenges of Science. Issue III, p.: 91-95. https://doi.org/10.31643/2020.013
\end{abstract}

\author{
Габиден Сулейменов \\ Әл-Фараби атындағы ҚазҰУ, Қазақстан \\ E-mail: gabiden1604@gmail.com \\ ORCID ID 0000-0002-9341-7408
}

\section{Больцманның стационар емес сызықсыз бірөлшемді төртмоменттік теңдеулер жүйесі үшін алғашқы-шеттік есеп}

\footnotetext{
Абстракт. Бұл мақалада Больцманның бірөлшемді сызықсыз моменттік теңдеулер жүйесінің екінші жуықтауы (төртмоменттік теңдеулер жүйесі) үшін алғашқы және шеттік есеп үшін шекаралық шарттардың қойылымы және олардың қисындылығы анықталады. Максвелл-Аужан шекаралық шартын қанағаттандыратын Больцманның бірөлшемді стационар емес сызықсыз моменттік теңдеулер жүйесінің екінші жуықтауы үшін алғашқы-шеттік есеп үшін теорема қарастырылып, осы теореманы дәлелдеу арқылы берілген есептердің жалғыз шешімдері бар екені дәлелденеді. Газ динамикасындағы көптеген есептерде газдың толық күйін молекулалардың микроскопиялық таралу функциясы арқылы сипаттаудың қажеттілігі жоқ екені белгілі. Сол себепті макроскопиялық газодинамикалық айнымалыларын (тығыздық, гидродинамикалық орташа жылдамдық, температура) қолдана отырып газды сипаттаудың оңайырақ жолын іздеген абзал. Бұл айнымалылар молекулалардың микроскопиялық таралу функциясының моменттері арқылы анықталатындықтан, біз Больцман теңдеуінің әртүрлі моменттерін талдау мәселесіне кездесеміз. Моменттік теңдеулерді зерттей отырып, біз молекулалардың микроскопиялық таралу функциясының өзі туралы және моменттік әдістің жинақтылығы
} 
жағдайында бірнеше ақпарат аламыз. Жоғарыда айтылғандардан Больцман теңдеулері және моменттік жүйелер үшін алғашқы, алғашқы-шеттік және шекаралық есептерді зерттеу өзекті екенін көруге болады.

Кілттік сөздер: Больцман моменттік теңдеулер жүйесі, Владимиров-Маршак шекаралық шарты, Максвелл-Аужан шекаралық шарты, итерация алгоритмдері.

\section{Есептің қойылуы.}

$$
\begin{gathered}
\frac{\partial w}{\partial t}+A \frac{\partial u}{\partial x}=0, \\
\frac{\partial u}{\partial t}+A^{T} \frac{\partial w}{\partial x}=J(u, w), \quad x \in(-a, a), \quad t>0, \\
w(0, x)=w_{0}(x), \quad u(0, x)=u_{0}(x), \quad x \in[-a, a], \\
\left(A u^{+} \mp B w^{+}\right)(t, \pm a)=\left(A u^{-} \pm B w^{-}\right)(t, \pm a) \pm \frac{1-\beta}{\alpha \sqrt{\pi}} F .
\end{gathered}
$$

(1) Больцманның стационар емес бір өлшемді төртмоменттік теңдеулер жүйесінің (2) алғашқы шартты және (3) Максвелл-Аужанның макроскопиялық шекаралық шартын қанағаттандыратын жалғыз шешімін табу керек. Мұндағы,

$$
\begin{aligned}
& A=\frac{1}{\alpha}\left(\begin{array}{lll}
1 & 2 / \sqrt{3} & -\sqrt{2 / 3}
\end{array}\right), A^{T}=\frac{1}{\alpha}\left(\begin{array}{lll}
1 & 2 / \sqrt{3} & -\sqrt{2 / 3}
\end{array}\right)^{T}, B=\frac{1}{\alpha \sqrt{\pi}}(2 \sqrt{2}) \text {, } \\
& w=f_{01}, u=\left(f_{00}, f_{02}, f_{10}\right)^{\prime}, \quad F=\frac{1}{4 \sqrt{2}}, \quad J(u, w)=\left(0, I_{02}, 0\right)^{\prime} .
\end{aligned}
$$

Больцманның (1) моменттік теңдеулер жүйесінің екінші жуықтауы үшін Максвелл-Аужанның (3) шекаралық шарттарын қанағаттандыратын алғашқы-шеттік есептің уақыт бойынша үзіліссіз, ал $x$ бойынша квадрат қосындыланатын функциялар кеңістігінде жалғыз шешуі бар екендігін дәлелдейік ( $\beta=1$-айналы шағылысу жағдайын қарастырамыз).

Tеорема. Егер $U_{0}=\left(w_{0}(x), u_{0}(x)\right) \in L^{2}[-a, a]$, онда (1)-(3) есептің $[-a, a] \times[0, T]$ облысында $C\left([0, T] ; L^{2}[-a, a]\right)$ кеңістігіне жататын жалғыз шешуі бар және ол шешу $U=(w, u)$ үшін

$$
\|U\|_{C\left([0, T]: L^{2}[-a, a]\right)} \leq C_{1}\left\|U_{0}\right\|_{L^{2}[-a, a]}
$$

априорлық баға орындалады, $C_{1}$ тұрақты шамасы $U$-дан тәуелсіз және

$$
T \sim O\left(\left\|U_{0}\right\|_{L^{2}[-a ; a]}^{-1}\right)
$$

Дәлелдеуі: $U_{0} \in L^{2}[-a, a]$ (4) априорлық бағаны дәлелдейміз. (1) жүйенің 1-ші теңдеуін $w$-ға, ал 2-ші теңдеуін $u$-ға көбейтіп - $a$-дан $a$-ға дейін интегралдаймыз:

$$
\frac{1}{2} \frac{d}{d t} \int_{-a}^{a}[(u, u)+(w, w)] d x+\int_{-a}^{a}\left[\left(A \frac{\partial u}{\partial x}, w\right)+\left(A^{\prime} \frac{\partial w}{\partial x}, u\right)\right] d x=\int_{-a}^{a}(J, u) d x
$$

Бөліктеп интегралдау формуласын қолданамыз: 


$$
\frac{1}{2} \frac{d}{d t} \int_{-a}^{a}[(u, u)+(w, w)] d x+\left.\left(w^{-}, A u^{-}\right)\right|_{x=a}-\left.\left(w^{-}, A u^{-}\right)\right|_{x=-a}=\int_{-a}^{a}(J, u) d x
$$

(3) шекаралық шарттарды пайдаланып (5) теңдікті мына түрде жазамыз:

$$
\begin{gathered}
\frac{1}{2} \frac{d}{d t} \int_{-a}^{a}[(u, u)+(w, w)] d x+\left.\left(B w^{-}, w^{-}\right)\right|_{x=a}+\left.\left(B w^{-}, w^{-}\right)\right|_{x=-a}- \\
-\left.\left(\left(A u^{+}-B w^{+}\right), w^{-}\right)\right|_{x=-a}+\left.\left(\left(A u^{+}+B w^{+}\right), w^{-}\right)\right|_{x=a}=\int_{-a}^{a}(J(u, w), u) d x
\end{gathered}
$$

$U$ векторының сфералық кескінделген түрін пайдаланамыз, яғни $U(t, x)=r(t) \omega(t, x)$, мұндағы

$$
\omega(t, x)=\left(\omega_{1}(t, x), \omega_{2}(t, x)\right)^{\prime}, \quad r(t)=\|U(t)\|_{L^{2}[-a, a]}, \quad\|\omega\|_{L^{2}[-a, a]}=1 .
$$

$w=r(t) \omega_{1}(t, x), \quad u=r(t) \omega_{2}(t, x)$ өрнектерін (6) теңдікке қоямыз

$$
\frac{d r}{d t}+r P(t)=r^{2} Q(t)
$$

мұндағы, $P(t)=\left.\left(B \omega_{1}^{-}, \omega_{1}^{-}\right)\right|_{x=a}+\left.\left(B \omega_{1}^{-}, \omega_{1}^{-}\right)\right|_{x=-a}+\left[\left.\left(A \omega_{2}^{+}, \omega_{1}^{-}\right)\right|_{x=a}+\left.\left(B \omega_{1}^{+}, \omega_{1}^{-}\right)\right|_{x=a}+\right.$ $\left.+\left.\left(B \omega_{1}^{+}, \omega_{1}^{-}\right)\right|_{x=-a}-\left.\left(A \omega_{2}^{+}, \omega_{1}^{-}\right)\right|_{x=-a}\right], Q(t)=\int_{-a}^{a}\left(J\left(\omega_{1}, \omega_{2}\right), \omega_{1}\right) d x$

(7) жай дифференциал теңдеудің

$$
r(0)=\left\|U_{0}\right\|=\left\|U_{0}\right\|_{L^{2}[-a ; a]}
$$

алғашқы шартты қанағаттандыратын шешуін іздейміз.

(7)-(8) есептің дәл шешуі мына түрде жазылады:

$$
r(t)=\left\{\exp \left(\int_{0}^{t} P(\tau) d \tau\right)\left[\frac{1}{\left\|U_{0}\right\|}-\int_{0}^{t} Q(\tau) \exp \left(-\int_{0}^{\tau} P(\xi) d \xi\right) d \tau\right]\right\}^{-1}
$$

Егер $\quad R(t) \equiv \int_{0}^{t} Q(\tau) \exp \left(-\int_{0}^{\tau} P(\xi) d \xi\right) d \tau \leq 0 \forall t, \quad$ онда $\quad r(t) \quad$ функциясы $\quad \forall t \in[0,+\infty) \quad$ үшін шенелген.

$R(t)>0$ болсын. $T_{1}$ арқылы мына теңдік нөлге айналатын уақыт мезетін белгілейік:

$$
\frac{1}{\left\|U_{0}\right\|}-\int_{0}^{T_{1}} Q(\tau) \exp \left(-\int_{0}^{\tau} P(\xi) d \xi\right) d \tau=0
$$


Сонда $r(t)$ функциясы кез-келген $T<T_{1}$ теңсіздігін қанағаттандыратын $T$ үшін орындалады, мұндағы $T_{1} \sim O\left(\left\|U_{0}\right\|^{-1}\right)$. Бұдан $\forall t \in[0, T]$ үшін (4) априорлық баға орындалады.

(1)-(3) есептің шешуінің бар екендігін Галеркин тәсілімен дәлелдейміз.

$\left\{\omega_{l}(x)\right\}_{l=1}^{\infty}$ функциялар жиыны $L^{2}[-a, a]$ кеңістігіндегі базис болсын. Кез-келген бүтін $m$ оң саны үшін (1)-(3) есептің жуық $U_{m}$ шешуін төмендегі теңдіктер арқылы анықтаймыз:

$$
\begin{gathered}
U_{m}=\sum_{j=1}^{m} c_{j m}(t) \omega_{j}(x), \\
\int_{-a}^{a}\left(\left(\frac{\partial U_{m}}{\partial t}+A_{1} \frac{\partial U_{m}}{\partial x}\right), \omega_{i}(x)\right) d x=\int_{-a}^{a}\left(J\left(U_{m}\right), \omega_{i}(x)\right) d x, \quad i=\overline{1, m}, t \in(0, T], \\
\left.U_{m}\right|_{t=0}=U_{0 m}(x), x \in R \\
\left.\left(A u_{m}^{-} \mp B w_{m}^{-}\right)\right|_{x=\mp a}=\left.\left(A u_{m}^{+} \pm B w_{m}^{+}\right)\right|_{x= \pm a} .
\end{gathered}
$$

мұндағы $U_{0}$ функциясының $L^{2}$ кеңістігіндегі проекциясы $U_{0 m}$. $c_{j m}(t)$ коэффициенттерін мына теңдеулерден анықтаймыз:

$$
\begin{gathered}
\sum_{j=1}^{m}\left\{\frac{d c_{j m}}{d t} \int_{-a}^{a}\left(v_{j}, v_{i}\right) d x+c_{j m}\left[\left.\left(B v_{j}^{-(1)}, v_{i}^{-(1)}\right)\right|_{x=a}+\left.\left(B v_{j}^{-(1)}, v_{i}^{-(1)}\right)\right|_{x=-a}+\right.\right. \\
+\left.\left(B v_{i}^{-(1)}, v_{j}^{-(1)}\right)\right|_{x=a}+\left.\left(B v_{i}^{-(1)}, v_{j}^{-(1)}\right)\right|_{x=-a}+\left.\left(\left(A v_{i}^{+(2)}+B v_{i}^{+(1)}\right), v_{j}^{-(1)}\right)\right|_{x=a}- \\
-\left.\left(\left(A v_{i}^{+(2)}-B v_{i}^{+(1)}\right), v_{j}^{-(1)}\right)\right|_{x=-a}+\left.\left(\left(A v_{j}^{+(2)}+B v_{j}^{+(1)}\right), v_{i}^{-(1)}\right)\right|_{x=a}- \\
\left.-\left.\left(A v_{j}^{+(2)}-B v_{j}^{+(1)}, v_{i}^{-(1)}\right)\right|_{x=-a}-\int_{-a}^{a}\left(\left(A \frac{\partial v_{i}^{(2)}}{\partial x}, v_{j}^{(1)}\right)+\left(A^{\prime} \frac{\partial v_{i}^{(1)}}{\partial x}, v_{j}^{(2)}\right)\right) d x\right\}= \\
=\int_{-a}^{a}\left(J\left(\sum_{j=1}^{m} c_{j m} v_{j}\right), v_{i}\right) d x, \quad i=\overline{1, m}, t \in(0, T] \\
c_{i m}(0)=d_{i m}, \quad i=\overline{1, m},
\end{gathered}
$$

$d_{i m}$ тұрақтысы $U_{0 m}$-нің $i$-ші компоненті.

(1) теңдікті $c_{i m}(t)$-ға көбейтіп $i$ бойынша 1-ден $m$-ге дейін қосындылаймыз:

$$
\int_{-a}^{a}\left(\left(\frac{\partial U_{m}}{\partial t}+A_{1} \frac{\partial U_{m}}{\partial x}\right), U_{m}\right) d x=\int_{-a}^{a}\left(\left(J\left(U_{m}\right), U_{m}\right) d x\right.
$$


Жоғарыда келтірілген әдіс бойынша кез-келген $\left[0, T_{m}\right]$ интервалында $r_{m}(t)$ шенелген, $U_{m}(t, x)=r_{m}(t) \omega_{m}(t, x), T_{m} \approx O\left(\left\|U_{0 m}\right\|^{-1}\right), T_{m} \geq T \forall m$, және

$$
\left\|U_{m}\right\|_{C\left([0 ; T]: L^{2}[-a ; a]\right)} \leq C_{2}\left\|U_{0}\right\|_{L^{2}[-a ; a]},
$$

(1)-(3) немесе (13)-(14) есептің шешуі бар екендігі (15) априорлық бағадан шығады.

Сонымен (9)-(12) есептің жуық шешулері $\left\{U_{m}\right\}$ тізбегі $C\left([0 ; T] ; L^{2}[-a ; a]\right)$ функциялар кеңістігінде бірқалыпты шенелген. Біртекті $\tau E+\frac{1}{\alpha} A \xi$ теңдеулер жүйесінің тек нөлге тең тривиал шешуі бар. $C\left([0 ; T] ; L^{2}[-a ; a]\right)$ кеңістігінде $U_{m} \rightarrow U$ және $J\left(U_{m}\right) \rightarrow J(U)$ дәлелдейміз. Стандарт әдістің көмегімен шек $U$ функция (1)-(3) есептің шешуі екенін дәлелдейміз.

Теорема дәлелденді.

Мақалаға сілтеме: Сулейменов Г., (2020), Больцманның стационар емес сызықсыз бірөлшемді төртмоменттік теңдеулер жүйесі үшін алғашқы-шеттік есеп. Challenges of Science. Issue III, p.: 9195. https://doi.org/10.31643/2020.013

\section{Пайдаланылған әдебиеттер}

[1] Черчиньяни К. Теория и приложения уравнения Больцмана. - М.: Мир, 1978.

[2] Коган М.Н. Динамика разреженного газа. - М.: Наука, 1967.

[3] Сакабеков А. Начально-краевые задачи для системы моментных уравнений Больцмана. - Алматы: Ғылым, 2002. 276 б.

[4] Sakabekov A. Auzhani Y. Boundary conditions for the one-dimensional nonlinear nonstationary Boltzmann's moment system equations // Journal of Mathematical Physics. - 2014. - №55(123507).

[5] Akhmetova A., Toktaubay A., Kassymova G., Apendiyev T., (2020). Issledovaniye problemy formirovaniya dukhovnonravstvennykh kachestv starsheklassnikov [Study of the problem of the formation of spiritual and moral qualities of high school students]. Challenges of Science. Issue III, p.: 76-82. https://doi.org/10.31643/2020.011

[6] Retnawati H., Sulistyaningsih E., Rasmuin R. (2020), How to Teach Mathematical Concept Easily? (Learning Trajectory of Two-Variable Linear Equation System Topic in Junior High School). Challenges of Science. Issue III, 2020. Pp.: 5-13. https://doi.org/10.31643/2020.001

[7] Tartar L. Some existence theorems for semilinear hyperbolic systems in one space variable // MRC.Report. - 1980. №2164.

\section{References}

[1] CHepchin'yani K. Teopiya i ppilozheniya upavneniya Bol'tsmana. - M.: Mip, 1978.

[2] Kogan M.N. Dinamika pazpezhennogo gaza. - M.: Nauka, 1967.

[3] Cakabekov A. Nachal'no-kpaevye zadachi dlya cictemy momentnyx upavneniy Bol'tsmana. - Almaty: Ġylym, 2002. - 276 b.

[4] Sakabekov A. Auzhani Y. Boundary conditions for the one-dimensional nonlinear nonstationary Boltzmann's moment system equations // Journal of Mathematical Physics. - 2014. - №55(123507).

[5] Akhmetova A., Toktaubay A., Kassymova G., Apendiyev T., (2020). Issledovaniye problemy formirovaniya dukhovnonravstvennykh kachestv starsheklassnikov [Study of the problem of the formation of spiritual and moral qualities of high school students]. Challenges of Science. Issue III, p.: 76-82. https://doi.org/10.31643/2020.011

[6] Retnawati H., Sulistyaningsih E., Rasmuin R. (2020), How to Teach Mathematical Concept Easily? (Learning Trajectory of Two-Variable Linear Equation System Topic in Junior High School). Challenges of Science. Issue III, 2020. Pp.: 5-13. https://doi.org/10.31643/2020.001

[7] Tartar L. Some existence theorems for semilinear hyperbolic systems in one space variable // MRC.Report. - 1980. №2164. 